REVISTA DE ESTUDIOS E INVESTIGACIÓN

EN PSICOLOGÍA Y EDUCACIÓN

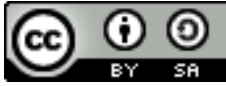

ISSN: 1138-1663; elSSN: 2386-7418

UDC / UMinho

2021, Vol. 8, No. 2, 198-210.

DOI: https://doi.org/10.17979/reipe.2021.8.2.8397

\title{
Nursing personnel training: a pilot study on attitude change, through a workshop on ethics and humanities
}

\section{Formación del personal de Enfermería: un estudio piloto sobre cambio de actitudes, a través de un taller sobre ética y humanidades}

Guillermo Rafael Cantú-Quintanilla (D) https://orcid.org/0000-0002-3493-2207

Centro Interdisciplinario de Bioética, Universidad Panamericana https://www.up.edu.mx/es/escuelas/mex/centro-interdisciplinario-de-bioetica Guadalajara, Jalisco - México

Nuria Aguiñaga-Chiñas (D) https://orcid.org/0000-0002-3339-5809

Escuela de Psicología Universidad Panamericana

https://www.up.edu.mx/es/escuelas/mex/escuela-de-psicologia

Anneke Farías-Yapur (DiD https://orcid.org/0000-0002-7787-6778

Centro Interdisciplinario de Bioética, Universidad Panamericana

https://www.up.edu.mx/es/escuelas/mex/centro-interdisciplinario-de-bioetica

Ciudad de México - México

Correspondence related to this article: Guillermo Rafael Cantú-Quintanilla - gcantu@up.edu.mx 


\begin{abstract}
Nursing has emerged as one of the main professions with a humanistic sense specialized in health care. The accent on personal development favored by training in humanities allows for questioning whether a training specifically focused on the workplace abilities enhances personal fulfilment at work. A pilot workshop on Ethics and Humanities at Work was offered in tertiary hospital to assess the influence of ethics and humanities in attitude toward work. Nineteen nurses completed the workshop; attitude towards change and attitude towards teamwork increased significantly. This pilot study found that the workshop influenced attitude towards change at work and teamwork. Since an attitude is made up of the cognitive, affective, and behavioral components, the change in one of these has the capacity to modify part of the others.
\end{abstract}

Keywords: Nursing education research, nursing ethics, humanities at work, attitude towards work, attitude change, workshop

\title{
Resumen
}

La enfermería se ha perfilado como una de las principales profesiones con sentido humanista especializado en el cuidado de la salud. El acento en el desarrollo personal que favorece la formación en humanidades permite cuestionar si una formación centrada en las habilidades laborales potencia la realización personal en el trabajo. Se ofreció un taller piloto de Ética y Humanidades en el Trabajo en un hospital para evaluar la influencia de la ética y las humanidades en la actitud hacia el trabajo. Diecinueve enfermeras completaron el taller; la actitud hacia el cambio y actitud hacia el trabajo en equipo mejoraron significativamente. En este estudio se encontró que el taller influyó en la actitud hacia el cambio en el trabajo y el trabajo en equipo; dado que una actitud está formada por los componentes cognitivo, afectivo y conductual, el cambio en uno de estos tiene la capacidad de modificar parte de los demás.

Palabras clave: investigación en educación de Enfermería, ética en Enfermería, humanidades en el trabajo, actitud hacia el trabajo, cambio de actitudes, taller 
Throughout its development, Nursing has emerged as one of the main professions with a humanistic sense specialized in health care. Due to the characteristics of care and the closeness to the patients, the Nursing staff generally has a greater involvement with them. This has proven to have a very positive effect on health promotion, prevention, and care (Blasco-León \& OrtizLuis, 2016). Therefore, this profession should not be reduced to the technical domain of health care and relief (García Moyano 2015); however, techniques have been perfected, there have been scientific and technological advances, which influence the professional development, leaving aside that the essence of Nursing is to respect life and to provide professional care for the patients (Juárez-Rodríguez \& García Campos, 2009).

Nurses should manage competences, understood as the set of behaviors that includes knowledge, skills and personal attributes that are essential for the development of their job, including: understanding and judgment; cognitive, technical, and interpersonal skills among others (Soto et al., 2014). Considering these, the role of nursing professionals always contributes to the improvement in the quality of life, the promotion of health and the reduction of diseases, for the patients, their families, and their communities (De Arco-Canoles \& Suarez-Calle, 2018).

Nursing's main ethical axis is the Ethics of Care. It proposes to focus on people, by considering their context to avoid making moral decisions that are inconsistent with their situation (Faerman, 2015). The ethics of care is a commitment to justice that allows detecting, recognizing, and attending the needs of the people under care (Romero de San Pío, 2012). To apply this commitment, it is important to convey the necessary knowledge and attitude (Escudero, 2003); since women are generally more opened to ethics and its involvement in their formation (Morales et al., 2015), this allows us to have a better approach to these healthcare workers.

In addition to facilitating the practice of Ethics of Care and benefiting patients and the health system (Carlin \& Strong, 1995), training in humanities benefits Nursing staff itself, as it provides greater personal development and not exclusively technical growth (Sánchez, 2014). This development in health personnel also contributes to the formation and maintenance of collaborative interpersonal relationships and conflict resolution (Goodstein et al., 2015). This is relevant, since conflictive interpersonal relationships in the work environment can affect the psychosocial well-being of health workers (Blanch et al., 2010; Sharma, 2016).

The accent on personal development favored by training in humanities allows for questioning whether a training specifically focused on the workplace abilities enhances personal 
fulfillment at work (Schleicher et al., 2015), which can and should be achieved in this space (Fernández-Otero, 1978; Valentine et al., 2011).

Social interactions have a distinctive role in developing the human consciousness, that is formed in stages, each of which is a complex and dialectical process of dynamic changes, mediated by instruments (Oliveira et al., 2017). Since work can be a means to develop human virtues, a positive attitude towards work could aim attain the previous goal. Therefore, a workshop on Ethics and Humanities at Work was offered in tertiary hospital, to a group of nurses that voluntarily decided to participate.

The present work sought to document if motivation to change can favor personal development (Llano, 2002), a disposition that can be enhanced when the Ideal of Virtue and the possibility of achieving a Good Life becomes attractive. Thus, the main objective consisted in evaluating the attitude towards work and change in a small group of Nursing personnel of a Health Institute (Third Level Hospital), before and after participating in a workshop on Ethics and Humanities at Work; to obtain initial data that allowed us to improve the workshop and applied it to different hospital areas; other goals included to describe how the workshop influences attitude towards change and work, teamwork, and job well-being. Therefore, we sought to find an improvement in attitude towards work and change, and in general wellbeing in nursing personal after the workshop, compared to the prior evaluation.

\section{Method}

\section{Participants}

A total of 19 nurses completed the five sessions of the pilot workshop and answered all the questionnaires at two different times. The age means was 46 years old ( $S D=7.42$ ), $75 \%$ had children, and over $55 \%$ had an educational level superior to a master's degree. $90 \%$ of the participants had more than 16 years of experience and had morning shift, and $80 \%$ had personnel under their command (Table 1).

\section{Inclusion criteria}

Nursing staff from the hospital, who volunteered to participate in the workshop on Ethics and Humanities at Work, and who were enrolled at the hospital by the time of the evaluation. They must have had $80 \%$ attendance of the course sessions and completed measurements before and after the workshop. 
Table 1

Participants' sociodemographic data

\begin{tabular}{|c|c|c|c|c|c|}
\hline Participants' characteristics & $n$ & $\%$ & Participants' characteristics & $n$ & $\%$ \\
\hline Children & & & Contract & & \\
\hline No children & 5 & 26 & Base & 9 & 47 \\
\hline 1-2 children & 12 & 63 & Trust & 9 & 47 \\
\hline 3-4 children & 2 & 11 & Regularized & 1 & 6 \\
\hline Marital status & & & Personnel in charge & & \\
\hline Single & 6 & 31 & Yes & 15 & 79 \\
\hline Married & 8 & 42 & No & 4 & 21 \\
\hline Free Union & 3 & 16 & Education level & & \\
\hline Divorced & 1 & 5 & Bachelor's degree & 5 & 26 \\
\hline Widow & 1 & 5 & Specialty & 3 & 16 \\
\hline Seniority & & & Master's degree & 9 & 47 \\
\hline$<1$ year & 1 & 5 & Doctor's degree & 2 & 11 \\
\hline $11-15$ years & 1 & 5 & Position & & \\
\hline $16-20$ years & 2 & 11 & Executive & 2 & 10 \\
\hline $21-25$ years & 3 & 16 & Middle command & 14 & 78 \\
\hline$>25$ years & 12 & 64 & Operative & 3 & 12 \\
\hline \multicolumn{6}{|l|}{ Shift } \\
\hline Morning & 18 & 94 & & & \\
\hline Other & 1 & 6 & & & \\
\hline
\end{tabular}

\section{Instruments}

Questionnaire of general knowledge of ethics and humanities (ECG): Questionnaire developed for the present investigation from the contents included in the five sessions of the Ethics and Humanities Workshop. From each topic (Anthropology, Ethical principles of conduct, Labor Virtues, The family in today's society, and Values hierarchy), five items were developed with the objective of evaluating the knowledge before and after the intervention; it is formed by a total of 25 multiple-choice questions.

Goldberg's General Health Questionnaire (CGS): Reduced version, in Spanish, of the Goldberg (1972) questionnaire (Morales-Carmona et al., 2008): consist of 15 questions answered on a Likert-type scale and aims to evaluate the general health state of the participants. It has a Cronbach's alpha of .91.

Blanch Labor Well-being Questionnaire (Blanch et al., 2010): Likert-type scale that is divided into two factors and 6six subscales, psychosocial. The Psychosocial well-being factor includes: affect scale, competence scale and expectations scale; sideand the Side effect factor includes: somatization scale, wear scale and alienation scale. Cronbach's alpha are between .82 and .96.

Questionnaire to measure the Quality of Work-Life of the Human Capital of the Ministry of Health (Hernández-Vicente et al., 2017): Contains 66 items. The first section collects 
sociodemographic data, and the second section assesses the quality of work life on a Likert-type scale.

Attitude towards change scale (Mánica Zuccolotto, 2005): Through 84 items on a Likert-type scale, it seeks to evaluate the attitude of health personnel to changes that frequently occur in the workplace. The instrument is divided into two dimensions, attitude towards change (Cronbach's alpha $=.91)$ and attitude towards teamwork (Cronbach's alpha $=.94)$.

\section{Procedure}

This was a quasi-experimental, pretest-postest study that intends to compare the utility of an Ethics and Humanities Workshop in a Nursing staff group of a tertiary hospital. For this study, the Nursing staff of the hospital was invited to participate through the Nursery head office, to which a group of nurses volunteered; initially, 20 nurses participated, of which 19 covered $80 \%$ of attendance to accredit the course.

The Ethics and Humanities at Work workshop was divided into five sessions of two hours each, once a week. The topics were Philosophical Anthropology, Ethical Principles of Behavior, Virtues at Work, Family in Contemporary Society, and Hierarchy of Values according to different authors. Instruments were applied before and after the workshop to measure its impact

This workshop was driven and promoted by the Institute's research department. Data obtained was protected by the Mexican NOM-012-SSA3-2012 for the criteria for the execution of research projects for human health, that stablishes that no informed consent letter is needed in cases of research without risk or with minimal risk. After previous pilot sessions, the workshop was reorganized in order to apply the instruments considered to assess attitude change, and to improve the information intended for Nursing staff.

For the statistical analysis only the data from the nurses who completed $80 \%$ of assistance to the course, were considered.

The main objective of the Ethics and Humanities Workshop was to facilitate a positive change in attitude towards work, in addition to promoting the recognition of work as a means to develop human virtues, to find the meaning of human work and of one's own existence. With the intention of meeting the objectives of the workshop, two virtues were addressed in each workshop session, as shown in Table 2.

The workshop was divided into 5 sessions, one per week for 2 hours; and readings must be made by the participants before every session. During the first session, the five instruments were answered by all the participants; afterwards, in each session a small case was presented to 
introduce the virtue, which was later discussed. The operational definition of virtue was read, and a self-evaluation was carried out. With the result, a profile of virtues was configured for each participant. A month after the last session, all participants answered the same five instruments.

\section{Table 2}

Workshop structure

\begin{tabular}{ccc}
\hline Week & Topic & Virtues \\
\hline 1 & Anthropology & Generosity and prudence \\
2 & Ethical principles of conduct & Justice and perseverance \\
3 & Labor Virtues & Strength and order \\
4 & The family in today's society & Sobriety and responsibility \\
5 & Values hierarchy & Laboriousness and respect \\
\hline
\end{tabular}

\section{Data analysis}

Descriptive statistical analyzes were used for sociodemographic data. To find out if there were significant differences between the attitude towards change before and after the ethics workshop, the Wilcoxon T test was performed. To know the association between the increase in knowledge of ethics and humanities, and the increase in the attitude towards change, a partial correlation analysis was carried out controlling for influence of age, number of children, monthly income, seniority, and level of studies.

\section{Results}

The only male participant was removed from the sample to run the statistical analysis in order to analyze if sex was a significant variable in this experiment, since no significant differences were found, he was included back again for the global analysis.

First, the reliability of the Questionnaire of general knowledge of ethics and humanities (ECG), developed for the present investigation, was calculated. A value of KR20 $=.56$ was obtained.

Subsequently, differences between pre- and post-workshop scores were analysed. According to the Wilcoxon $T$ test, scores of General Examination of Knowledge and Attitude towards Change (dimensions attitude towards change and attitude towards teamwork) increased significantly after the Ethics and Humanities Workshop (Table 3).

No statistically significant differences were found between the scores before and after the workshop in the general health status of the participants (CGS), in the subscales of the Labor Well-being Questionnaire (BLG), nor in the Questionnaire to measure the Quality of Work Life (CVL) of the Human Capital of the Ministry of Health (Table 4). 


\section{Table 3}

Means before and after the Ethics and Humanities Workshop

\begin{tabular}{lccccc}
\hline Instrument & \multicolumn{2}{c}{ Pre } & \multicolumn{2}{c}{ Post } & \multirow{2}{*}{$Z(18)$} \\
\cline { 2 - 5 } & $M$ & $S D$ & $M$ & $S D$ & \\
\hline Questionnaire of general of ethics and humanities & 6.92 & $(1.23)$ & 7.71 & $(1.07)$ & $-2.02^{*}$ \\
Attitude towards change: & & & & & \\
a) Attitude towards change dimension & 177.94 & $(15.91)$ & 188.78 & $(9.35)$ & $-2.46^{*}$ \\
b) Attitude towards teamwork dimension & 162.89 & $(127.19)$ & 184.00 & $(12.84)$ & $-2.96^{*}$ \\
\hline
\end{tabular}

${ }^{*} p<.05$

Table 4

Mean scores per questionnaire, before and after workshop

\begin{tabular}{lccccccccc}
\hline \multirow{2}{*}{ Questionnaires } & \multicolumn{4}{c}{ Pre } & \multicolumn{7}{c}{ Post } & \multirow{2}{*}{$Z(18)$} \\
\cline { 2 - 10 }$n$ & $M$ & $S D$ & Min & Max & $M$ & SD & Min & Max & -0.60 \\
\hline CVL & 93.32 & 19.77 & 65 & 137 & 96.77 & 19.81 & 63 & 137 & -0.12 \\
BLG Affects & 59.17 & 10.64 & 26 & 70 & 57.94 & 13.22 & 13 & 70 & -0.52 \\
BLG Competences & 62.22 & 11.75 & 19 & 70 & 61.47 & 9.18 & 31 & 70 & -0.52 \\
BLG Expectations & 135.11 & 16.47 & 96 & 154 & 128.47 & 22.73 & 72 & 154 & -0.72 \\
BLG Somatization & 13.47 & 8.18 & 5 & 30 & 14.72 & 6.96 & 5 & 30 & -0.54 \\
BLG Attrition & 15.05 & 9.32 & 0 & 28 & 14.54 & 7.45 & 6 & 28 & -0.30 \\
CGS & 3.26 & 4.07 & 0 & 15 & 3.83 & 5.58 & 0 & 21 & -0.37 \\
\hline
\end{tabular}

Note. $p$ values for $Z>.05$, in all cases

To understand the extent to which the increase in knowledge about ethics and humanities is associated with the increase in attitude towards change, the difference of both variables was calculated before and after the workshop (EGC post - EGC pre; ACHC post - ACHC pre), and a partial correlation analysis was carried out. The influence of age, number of children, monthly income, seniority, and educational level was evaluated.

Only when controlling for age $(46.2(S D=7.32))$ was the partial association between ECG and ACHC significant, positive, and moderate, $r=.494, p=.037$. This is due to the fact that the distribution of scores for both scales had the shape of an inverse U: participants with ages in quartiles 2 and 3 had higher scores than those in quartiles 1 and 4 . Despite this, there were no statistically significant differences between quartiles, nor between extreme quartiles versus middle quartiles. Spearman's correlations showed that there was no statistically significant correlation between ECG and ACHC if age is not controlled, which indicates that age had enough influence controlling the relationship between ECG and ACHC. 


\section{Discussion}

Mclntyre (1996) presents three types of ethical schools: virtue ethics, duty ethics, and emotivism. The workshop that was offered follows the postulates of Virtue Ethics. Since virtue is presented as good in itself, we maintain that the Ideal of Virtue and a Good Life can motivate change and personal development, as the author defends in his work.

The main objective consisted in evaluating the attitude towards work and change in Nursing personnel before and after participating in a workshop on Ethics and Humanities at Work. In addition, we sought to know how the workshop influenced job well-being and other measures. The workshop influenced attitude towards change at work and teamwork in our sample. Since an attitude is made up of the cognitive, affective, and behavioral components, the change in one of these has the capacity to modify, even to a certain extent, part of the others (Blanch et al., 2010). In this sense, we may attribute the change in attitude towards change and teamwork to the understanding about the "Ideal of Virtue and the Good Life", as well as to the notion that these are attainable. In other words, the workshop's emphasis on the ability of work to perfect one's own human nature probably helped make work more pleasant.

No differences were found in the general state of health, in work well-being, or in the quality of work-life before and after the workshop. Possibly, this occurred because the benefits of awakening the desire for the Ideal of Virtue do not occur immediately. We hope that with time and with the implementation of new habits, changes will be obtained in the other variables. Further research is needed to test this hypothesis..

Regarding the third objective, an association was found only between general knowledge about ethics and attitude towards change and teamwork when controlling for age.

According to the results obtained, it is possible to say that after the Ethics and Humanities Workshop, the attitude towards work improved, as well as the knowledge about ethics. Breaking from naive optimism, it was sought to communicate that the Ideal of Virtue is noble, attractive, and is consistent with the improvement of human nature. The workshop emphasized work to achieve the Ideal of Virtue, and that it is possible to improve at work. We consider that the workshop on Ethics and Humanities at Work can be of great use to improve interpersonal relationships, the attitude towards change at work, and possibly the general well-being of people, since it seeks to approximate the ideal of the Good Life (McIntyre, 1996).

Nursing faces the challenge of finding the middle ground between keeping health systems at the forefront of technology and providing excellent human quality care that allows professionals to have greater proximity and sensitivity to the needs of their patients (García 
Moyano, 2015; Escudero, 2003). To avoid the displacement of the quality of care in favor of technologies, and to claim the relevance of quality care, it is convenient to offer workshops like the one that was given.

Nurses who participated responded to an open invitation, with the antecedent of a previous workshop for their fellow nurses, who perceived an enriching experience. Therefore, it is a motivated, receptive, and enthusiastic staff. It would be necessary to see how more conflictive participants respond and the effects of obligated attendance. It is important to increase the sample size to obtain greater clarity on the associations that exist between the variables. The instrument that measured the acquisition of knowledge in ethics and humanities must be refined, since there are only 5 items that measure each dimension. This does not allow for identifying if they really obtained the expected knowledge. Finally, there should be a longterm follow-up of the participants to assess if the attitude towards work improves as knowledge obtained in the Ethics and Humanities Workshop increases; that is, ethical knowledge and practice.

One of the main limitations of this project was that the instrument developed to measure the knowledge obtained by the participants, regarding ethics and humanities, was not validated before its application and needs further revising there are few items (five per area). However this original questionnaire has helped evaluate the assimilation of the theoretical contents of the workshop as fundamental guiding ideas of the humanities in nursing work.

Among other limitations we found that we worked with a small and mainly female group, which makes harder to generalize our results; nevertheless, data allow us to get to know the target population for this workshop to improve the contents and the evaluation methods. For future research we intend to validate the Questionnaire of general knowledge of ethics and humanities and enhance the recruiting model so that the sample is bigger and variate.

\section{Acknowledgements}

To Dr. Juan Garduño, from the Research Directorate of the Hospital Infantil de México for all the facilities to teach the Ethics and Humanities at Work Workshops.

To Mtra. Diana Ávila and Lic. Alejandra García for the logistical support for the workshops. Without the help of the authorities of the Nursing Department it would not have been possible to carry out this workshop. Our sincere thanks for your participation and enthusiasm.

To Mtra. Araceli Saldivar Flores head of the Nursing Department, to Mtra. Olivia Aguilar Guzmán Deputy Head of the Nursing Department and Mtra. Miroslava Iliana Carrasco González. 


\section{References}

BLANCH, Joseph; SAHAGÚN, Miguel; CANTERA, Leonor; \& CERVANTES, Genís (2010). Cuestionario de Bienestar Laboral General: Estructura y Propiedades Psicométricas. Revista de Psicología del Trabajo y de las Organizaciones; 26(2), 157-170. https://doi.org/10.5093/tr2010v26n2a7

BLASCO-LEÓN, Mónica; \& ORTIZ-LUIS, Silvia Rubí (2016). Ética y valores en enfermería. Revista de Enfermería del Instituto Mexicano del Seguro Social; 24(2), 145-149. http://revista enfermeria.imss.gob.mx/editorial/index.php/revista_enfermeria/article/view/104/

Carlin, William B.; \& Strong, Kelly C. (1995). A Critique of Western Philosophical Ethics: Multidisciplinary Alternatives for Framing Ethical Dilemmas. Journal of Business Ethics; 14 , 387-396. https://doi.org/10.1007/BF00872100

DE ARCO-CANOLES, Oneys del Carmen; \& SUAREZ-CALLE, Zuleima Karina (2018). Rol de los profesionales de enfermería en el sistema de salud colombiano. Universidad y Salud, 20(2), 171-182. https://doi.org/10.22267/rus.182002.121

ESCUDERO, Bibiana (2003). Humanismo y tecnología en los cuidados de enfermería desde la perspectiva docente. Enfermería Clínica; 13(3), 164-170. https://doi.org/10.1016/S11308621(03)73800-5

FAERMAN, Romina (2015). Ética del cuidado: Una mirada diferente en el debate moral. Revista de Teoría del Derecho de la Universidad de Palermo; 2(1), 123-146. https://www.palermo. edu/derecho/publicaciones/revista_teoria_derecho/ediciones.html

FERNÁNDEZ-OTERO, Oliveros (1978). Realización personal en el trabajo. Ediciones Universidad de Navarra (EUNSA).

GARCÍA MOYANO, Loreto (2015). La ética del cuidado y su aplicación en la profesión enfermera. Acta Bioethica, 21(2), 311-317. https://doi.org/10.4067/S1726-569X2015000200017

GOLDBERG, David P. (1972). The detection of psychiatric illness by questionnaire: A technique for the identification and assessment of non-psychotic psychiatric illness. Oxford, England: Oxford University Press.

GOODSTEIN, Jerry; BUTTERFIELD, Ken.; \& NEALE, Nathan (2015). Moral Repair in the Workplace: A Qualitative Investigation and Inductive Model. Journal of Business Ethics, 138(1), 17-37. https://doi.org/10.1007/s10551-015-2593-5

HERNÁNDEZ-VICENTE, Irma Alejandra; LUMBRERAS-GUZMÁN, Marivel; MÉNDEZ-HERNÁNDEZ, Pablo; ROJAS-LIMA, Elodia; CERVANTES-RODRÍGUEZ, Margarita; \& JUÁREZ-FLORES, Clara Arlina (2017). Validación de una escala para medir la calidad de vida laboral en hospitales 
públicos de Tlaxcala. Salud Pública de México, 59(2, mar-abr), 183-192. https://doi.org/ $10.21149 / 7758$

JUÁREZ-RODRÍGUEZ, Paula Alina; \& GARCÍA-CAMPOS, María de Lourdes (2009). La importancia del cuidado de enfermería. Revista de Enfermería del Instituto Mexicano del Seguro Social, 17(2), 109-111. http://revistaenfermeria.imss.gob.mx/editorial/index.php/revista_enfer meria/article/view/498

LLANO, Alejandro (2002). La vida lograda. Editorial Ariel.

MÁNICA ZUCCOLOTTO, Concepción (2005). Diseño y validación de instrumentos para medir Actitud al Cambio y Actitud al trabajo en equipo. [Conference presentation] IX Congreso Anual de la Academia de Ciencias de la Administración, A.C, Mérida, Yucatán, México. http://acacia.org.mx/busqueda/index_memorias.php

MACINTYRE, Alasdair (1996). Natural Law as Subversive: The Case of Aquinas. Journal of Medieval and Early Modern Studies. 26(1), 61-83. https://doi.org/10.1017/СBO97805 11606670.004

MORALES, Ana María; MORALES, Francisco Manuel; \& NARVÁEZ, Manuel Alejandro (2015). ¿Existen diferencias en función del sexo en comportamientos socialmente responsables en universitarios)? Revista de Estudios e Investigación en Psicología y Educación, 004-006. https://doi.org/10.17979/reipe.2015.0.06.93

MORALES-CARMONA, Francisco; PIMENTEL-NIETO, Diana; SÁNCHEZ-BRAVO, Claudia; \& HENALES-ALMARAZ, Consuelo (2008). Versión breve (15 reactivos) del Cuestionario General de Salud para la identificación oportuna de malestar psicológico en mujeres. Ginecología y Obstetricia de México, 76(6). https://ginecologiayobstetricia.org.mx/articulo /version-breve-15-reactivos-del-cuestionario-general-de-salud-para-la-identificacion-opor tuna-de-malestar-psicologico-en-mujeres

OLIVEIRA, Cristiane Simões; FIREMAN, Elton Casado; \& FILHO, Jenner Barreto Bastos (2017). Vigotsky, Bachelard e o ensino de ciências. Revista de Estudios e Investigación en Psicología y Educación, (04), 070-074. https://doi.org/10.17979/reipe.2017.0.04.2570

RODRÍGUEZ, Ángel (1989) Interpretación de las actitudes. En Ángel Rodríguez \& Julio Seoane Creencias, actitudes y valores [Tratado de Psicología General, 7] (pp.199-314). Alhambra Universidad.

ROMERO DE SAN PIO, Emilia (2012). Introducción a la ética del cuidado en enfermería de atención primaria. Revista de SEAPA (Sociedad de Enfermería Familiar y Comunitaria de Asturias), 10, 27-30. Disponible en: https://www.seapaonline.org/publicaciones/primaver-2012 
SÁNCHEZ, Miguel María (2014). Humanidades médicas: integrar arte y ciencia en Medicina. Revista Española de Cirugía Osteoarticular. 260(49), 187-196. http://www.cirugia-osteo articular.org/revistas/usuario/articulos/articulo.asp?idarticulo=2366

SCHLEICHER, Deidra; SMITH, Troy A.; CASPER, Wendy J.; WATT, John D.; \& GREGURAS, Gary J. (2015). It's all in the attitude: The role of job attitude strength in job attitude-outcome relationships. Journal of Applied Psychology, 100(4), 1259-1274. https://doi.org/10.1037/ a0038664

SHARMA, Dheeraj (2016). When fairness is not enough: Impact of corporate ethical values on organizational citizenship behaviors and worker alienation. Journal of Business Ethics. 150, 57-68. https://doi.org/10.1007/s10551-016-3107-9

SOTO-FUENTES, Paz; REYNALDOS-GRANDÓN, Katiuska; MARTíNEZ-SANTANA, Dayann; \& JEREZYÁÑEZ, Óscar (2014). Competencias para la enfermera/o en el ámbito de gestión y administración: desafíos actuales de la profesión. Aquichan, 14(1), 79-99; https://doi.org/ 10.5294/aqui.2014.14.1.7

VALENTINE, Sean; GODKIN, Lynn; FLEISCHMAN, Gary M.; KIDWELL, Roland; \& PAGE, Karen (2011). Corporate Ethical Values and Altruism: The Mediating Role of Career Satisfaction. Journal of Business Ethics; 101, 509-523. https://doi.org/10.1007/s10551-011-0739-7

Fecha de recepción: 11 de mayo de 2021. Fecha de revisión: 22 de septiembre de 2021. Fecha de aceptación: 28 de septiembre de 2021. Fecha de publicación: 1 de diciembre de 2021. 